УДК 004.4+519.6

DOI: https://doi.org/10.26642/ten-2019-2(84)-84-99

\author{
А.В. Морозов, к.т.н., доц. \\ Т.А. Вакалюк, к.пед.н., доц. \\ Д.С. Антонюк, к.пед.н. \\ В.В. Дідківський, магістрант \\ Державний університет «Житомирська політехніка»
}

\title{
Програмний комплекс створення та проведення числових симуляцій
}

\begin{abstract}
Актуальність. У сучасному світі набули широкого поширення бізнес-симулятори інтерактивні системи, які дозволяють організовувати та проводити симуляції економічних та сочіально-економічних процесів з достатньою реалістичністю. Водночас опитування, проведене серед студентів, показало недостатні знання та технічні навички студентів вітчизняних закладів вищої освіти у галузі розробки бізнес-симуляцій з використанням сучасних технологій та підходів розробки програмного забезпечення.

Мета статті полягає в описі розробки системи, яка дозволяє викладачам та студентам організовувати ц̌ проводити симулящії економічних $i$ соціально-економічних прочесів у навчальному прочесі.

Методи. В роботі було використано методи об'єктно-орієнтованого проектування, проектування програмних інтерфейсів, веб-програмування та дизайну.

Результати. У иій роботі було описано розробку програмного комплексу створення та проведення числових симуляцій. Для цього було визначено такі вимоги до програмного комплексу: система має бути у вільному доступі в мережі Інтернет; система має бути доступна з будьякого пристрою, який має доступ до мережі Інтернет, незалежно від типу операційної системи пристрою; система повинна мати сучасний дизайн, який адаптується до розширення екрана учасника; система повинна мати механізм розширення сторонніми симуляціями, які підтримують визначений АРI; система повинна мати простий інтерфейс, який мінімізує зусилля викладача та студентів при організаџії та проведенні симуляції.

У прочесі дослідження було обрано хмарну архітектуру програмного комплексу, що дозволяє організувати управління симуляцій учасниками за допомогою централізованого ресурсу. Розроблений програмний комплекс створення та проведення числових симуляцій складається 3 таких компонентів: SimulationLab.Admin, SimulationLab.Api.Models, SimulationLab.Engine, SimulationLab.Core, SimulationLab.Web.

У прочесі дослідження було встановлено, щчо використання засобів навчання, що збагачують пізнавальний досвід студентів та забезпечують вироблення умінь $і$ навичок, значною мірою залежить від зручності впровадження таких засобів у освітній процес викладачем, тому велика увага в роботі приділялася саме зручному впровадженню використання розробленої системи під час лекцій чи практичних занять. Система побудована з використанням сучасних технологій та архітектурних рішень.
\end{abstract}

Висновки. Використання розробленої системи значно спрощує доповнення теоретичного матеріалу практичними та дослідницькими видами навчальної діяльності в межах курсів математичного й соціально-економічних блоків у закладах вищої та загальної середньої освіти, корпоративних тренінгах та в межах заходів неформальної освіти.

Ключові слова: симуляція; числові симуляції; бізнес-симулятори; програмний комплекс; проектування.

Актуальність теми. В сучасному світі набули широкого поширення бізнес-симулятори інтерактивні системи, які дозволяють організовувати та проводити симуляції економічних і соціальноекономічних процесів $з$ достатньою реалістичністю [1]. Такі системи створені для візуалізації процесів та явищ, покращення засвоєння знань, вироблення навичок i сприянню формування та розвитку компетентностей і за умови ефективної інтеграції з навчальними задачами підвищують ефективність освітніх результатів [2].

Застосування бізнес-симуляторів у вивченні курсів фінансово-економічного спрямування стає необхідністю, забезпечуючи елементи активного навчання та практичну складову навчання. Лекції 3 використанням симуляторів можуть підвищити зацікавленість студента в дисципліні, демонструючи користь набутих теоретичних знань на практиці.

Водночас опитування, проведене серед студентів, показало недостатні знання та технічні навички студентів вітчизняних закладів вищої освіти у галузі розробки бізнес-симуляцій з використанням сучасних технологій та підходів розробки програмного забезпечення.

(C) А.В. Морозов, Т.А. Вакалюк, Д.С. Антонюк, В.В. Дідківський, 2019 
Аналіз останніх досліджень та публікації, на які спирається автор. Зокрема, застосування програмно-імітаційних комплексів у процесі навчання розглядали В.Адамс (W.K. Adams) [11], Б.Девейн (B.Devine) [13], Е.Кастронова (E.Castronova) [12], К.Перкінс (K.Perkins) [14], С.Фортман-Poe (S.FortmannRoe) [15], в Україні цю тему досліджували О.О. Мацюк [17], В.А. Пермінова [16], О.Б. Шендерук [16].

Метою статті є опис розробки системи, яка дозволяє викладачам та студентам організовувати та проводити симуляції економічних і соціально-економічних процесів у навчальному процесі.

Викладення основного матеріалу. Для досягнення поставленої мети було визначено такі вимоги до програмного комплексу: система має бути у вільному доступі в мережі Інтернет;

- система має бути доступна 3 будь-якого пристрою, який має доступ до мережі Інтернет, незалежно від типу операційної системи пристрою;

- система повинна мати сучасний дизайн, який адаптується до розширення екрана учасника;

- система повинна мати механізм розширення сторонніми симуляціями, які підтримують визначений API;

- система повинна мати простий інтерфейс, який мінімізує зусилля викладача й студентів при організації та проведенні симуляції.

Для виконання перерахованих вище вимог було сформовані такі задачі:

1. Розробка системи для додавання нових сторонніх симуляцій до програмного комплексу. Механізм розширення системи сторонніми симуляціями такий: розробник реалізовує визначені інтерфейси відповідно до своєї симуляції та розгортає свій додаток у мережі Інтернет. Для реєстрації нової симуляції в системі створення симуляцій необхідно додати маніфест, в якому обов'язково має бути вказано назву симуляції та шлях (URL) до місця, де система зможе знайти всі інші налаштування симуляції.

2. Розробка каталогу доступних симуляцій. Система має відображати усі симуляції, інформацію про яких вдалося успішно отримати, звернувшись по вказаному у маніфесті URL, інакше такі симуляції мають бути проігноровані. Кожна симуляція повинна бути представлена у вигляді заголовка та опису 3 правилами симуляції.

3. Розробка системи створення сеансу симуляції. Якщо симуляція підтримує декількох учасників, користувач повинен мати можливість створити багатокористувацький сеанс симуляції. Після створення сеансу симуляції користувач має побачити 2 коди доступу до сеансу: перший код для гравців, який вони зможуть використати, щоб приєднатися до сеансу симуляції та почати гру; другий для інструктора, який він чи вона зможе використати для того, щоб отримати доступ до сторінки презентації. Код для інструктора має бути прихованим у вигляді «зірочок», але повинна бути можливість його переглянути.

4. Розробка функціоналу сторінки презентації. Після створення сеансу симуляції інструктор за допомогою отриманого коду має отримати доступ до спеціальної сторінки презентації. На цій сторінці у верхній частині екрана завжди має бути відображена інформація про те, як приєднатися до сеансу симуляції, а саме: URL до форми входу в сеанс та код доступу. Сторінка інструктора повинна містити 4 вкладки:

a) «QR» - вкладка, на якій зображено код швидкого доступу, який містить зашифровану інформацію для миттєвого приєднання учасників до сеансу симуляції;

b) «Description» - вкладка, на якій зображено опис симуляції;

c) «Monitor» - вкладка, в якій зображено список вільних та зайнятих місць учасників сеансу симуляції разом з інформацією про останню активність учасників. Також, якщо симуляція це підтримує, тут має бути можливість примусово перевести учасника симуляції на наступний крок або замінити учасника ботом. Інформація про активність учасників має оновлюватися в режимі реального часу;

d) «Statistics» - вкладка, на якій представлена статистика сеансу. Може бути відсутньою, якщо симуляція не підтримує генерування статистики. Статистика має оновлюватися в режимі реального часу.

5. Розробка системи проходження симуляції з підтримкою декількох учасників.

6. Розробка системи проходження симуляції з підтримкою лише 1 учасника.

7. Розробка симуляції «The Market for Lemons Game» [4].

8. Розробка симуляції «The Red/Green Simulation» [5].

У процесі дослідження було обрано хмарну архітектуру програмного комплексу, що дозволяє організувати управління симуляцій учасниками за допомогою централізованого ресурсу (Інтернетсервісу). Також хмарна архітектура системи дозволяє застосовувати концепцію BYOD [7] (принеси свій власний пристрій) при проведенні симуляцій. Концепція BYOD дозволяє організовувати проходження симуляцій під час лекцій чи практичних занять.

Для забезпечення модульності програмного комплексу був застосований об'єктно-орієнтований метод програмування (ООП), який заснований на поданні програми у вигляді сукупності взаємодіючих об’єктів [6]. Таким чином, програма являє собою набір об'єктів, що мають стан та поведінку. Стійкість та керованість системи забезпечуються за рахунок чіткого розподілення відповідальності об'єктів (за кожну 
дію відповідає певний об’єкт), однозначного означення інтерфейсів взаємодії об'єктів та повної ізольованості внутрішньої структури об'єкта від зовнішнього середовища (інкапсуляції) [10].

Для того щоб система мала механізм розширення сторонніми симуляціями, які підтримують визначений API, було обрано архітектурний стиль мікросервісів, за яким єдиний застосунок будується як сукупність сервісів, кожен з яких працює окремо, комунікація між сервісами відбувається за допомогою НТТР. Сервіси будуються та розгортаються незалежно один від одного і можуть бути написані 3 використанням різних мов програмування [8].

Особливості архітектури мікросервісів, які використані при розробці програмного комплексу створення та проведення числових симуляцій: незалежна розробка; незалежне розгортання; незалежне масштабування; невелика кодова база зменшує кількість конфліктів; простота заміни однієї реалізації сервісу іншою; простота додавання нового функціоналу в систему; вихід 3 ладу одного сервісу не призводить до виходу з ладу всієї системи; кожен сервіс незалежно від інших може бути реалізований за допомогою будь-якої мови програмування [8].

Зважаючи на особливості архітектури мікросервісів було розроблено таку структуру програмного комплексу створення та проведення числових симуляцій (рис. 1):

1. «SimulationLab ASP.NET Core Web App»:

здійснює централізоване управління іншими сервісами, з якими спілкується через визначений API;

відповідає за збереження даних, в тому числі збереження даних про сеанси симуляцій;

відповідає за надання інформації клієнту;

відповідає за неможливість виникнення колізій між запитами декількох учасників однієї симуляції.

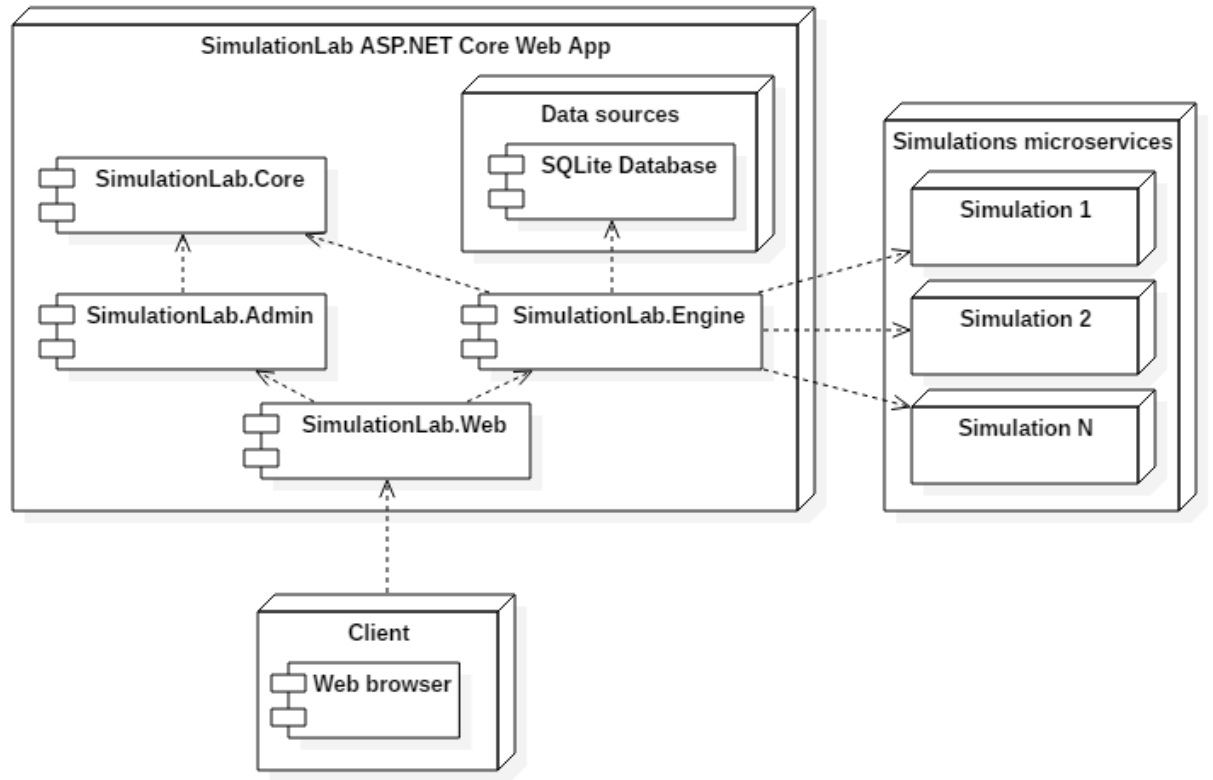

Рис. 1. Діаграма розгортання розроблюваної системи

2. Клієнт:

○ здійснює запити до основного сервера програмного комплексу;

○ відповідає за представлення даних клієнту.

3. Мікросервіси симуляцій:

○ $\epsilon$ незалежними програмами, тобто кожна окрема симуляція немає жодної інформації про іншу симуляцію;

○ декілька симуляцій можуть бути розгорнуті в межах одного домену, якщо вони написані на одній мові програмування;

○ реалізовують визначений API.

Обмін даними між сервісами відбувається за допомогою НТТР. Спілкування між основною системою та мікросервісами симуляцій здійснюється через визначений API, який має реалізувати кожна окрема симуляція. В розробленому програмному комплексі симуляції мають лише оброблювати дані, які приходять у запиті у форматі JSON, та повертати на основі цих даних відповідь у такому ж форматі.

Основним архітектурним шаблоном сервісу створення та проведення числових симуляцій було обрано MVC - шаблон, який передбачає поділ системи на три взаємопов'язані частини: модель даних, вигляд (інтерфейс користувача) та модуль керування [9]. Використання шаблону MVC забезпечує 
розділення відповідальності між компонентами в системі, що полегшує внесення змін і робить програму більш зрозумілою через зменшення ії складності.

Для опису найважливіших алгоритмів системи було розроблено діаграми активності.

На рисунку 2 зображено діаграму активності створення сеансу симуляції, яка складається 3 таких послідовних дій:

1. Користувач обирає симуляцію, сеанс якої він хоче створити.

2. Якщо створення сеансу симуляції потребує додаткових налаштувань, користувачу буде показано вікно з формою для заповнення додаткових даних.

3. Якщо створення сеансу симуляції не потребує додаткових налаштувань або потребує і додаткові дані успішно заповнені - сеанс симуляції буде створено.

4. Якщо симуляція підтримує сторінку презентації, в наступному вікні буде зображено 2 коди і кнопка для входу в сеанс симуляції як інструктор.

5. Інакше у вікні після створення сеансу симуляції буде зображено лише 1 код і кнопка для входу в сеанс як учасник симуляції.

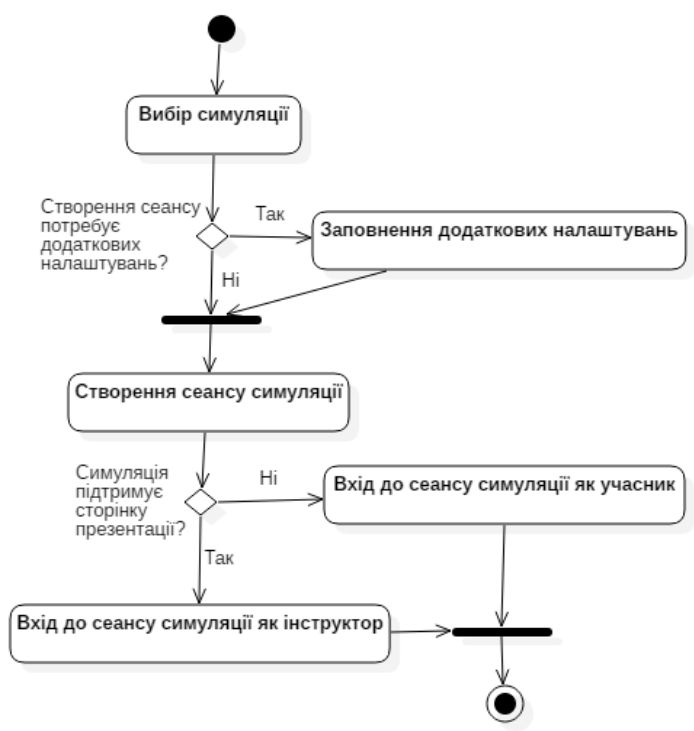

Рис. 2. Діаграма активності створення сеансу симуляиії

На рисунку 3 зображена діаграма активності проходження сеансу симуляції, яка складається з таких послідовних дій:

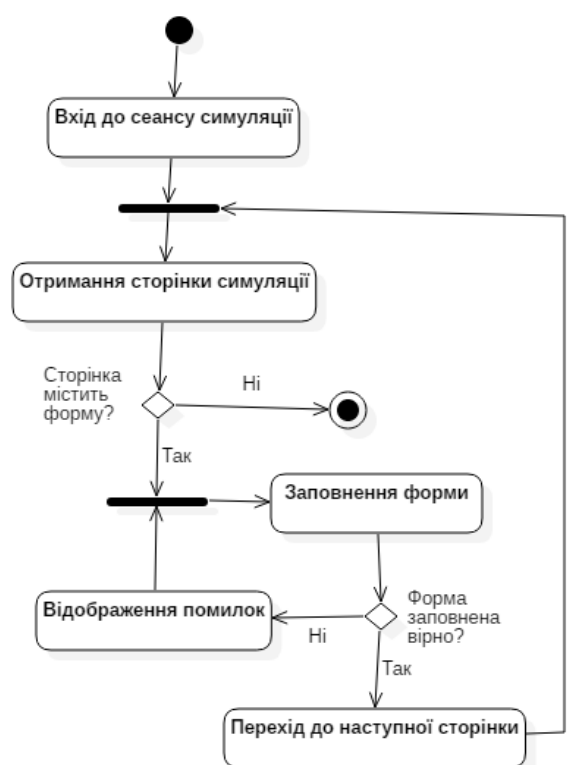

Рис. 3. Діаграма активності проходження сеансу симуляиії

1. Учасник підключається до сеансу симуляції за допомогою логіну.

2. Система отримує сторінку симуляції, яка відображається учаснику.

3. Якщо сторінка містить форму - учасник має заповнити іiі. 
4. Якщо форма була заповнена неправильно - система покаже учаснику помилки.

5. Якщо форма була заповнена правильно - учасник переходить на наступний крок.

6. Процес отримання сторінок і заповнення форм продовжується поки учасник не дійде до останньої сторінки, яка не містить форму для заповнення.

Для опису взаємозв'язків, внутрішню структуру і типи відносин між окремими сутностями програмного комплексу було розроблено діаграми класів.

Програмний комплекс створення та проведення числових симуляцій складається 3 таких компонентів:

1. SimulationLab.Admin - містить специфічні класи системи адміністратора сайту (рис. 4, табл. 1).

\begin{tabular}{|l|}
\hline \multicolumn{1}{|c|}{ AdminUserService } \\
\hline -settings: IOptions<AdminSettings $>$ \{readOnly\} \\
\hline «constructor»+AdminUserService(settings: IOptions<AdminSettings $>$ ) \\
+GetAdminUser(name: string): AdminUser \\
+Authenticate(name: string, password: string): AdminUser \\
-HashPassword(password: string, salt: string): string \\
\hline
\end{tabular}

\begin{tabular}{|l|}
\hline \multicolumn{1}{|c|}{ AdminUser } \\
\hline +Name: string \\
+Password: string \\
+Salt: string
\end{tabular}

\begin{tabular}{|c|}
\hline AdminSettings \\
\hline +Users: IList $<$ AdminUser $>$ \\
\hline
\end{tabular}

Puc. 4. Діаграма класів «SimulationLab.Admin»

Опис класів «SimulationLab.Admin»

\begin{tabular}{|c|l|}
\hline Назва класу & \multicolumn{1}{|c|}{ Опис } \\
\hline AdminUserService & Клас для роботи з користувачами системи адміністратора сайту \\
\hline AdminUser & Модель користувача системи адміністратора сайту \\
\hline AdminSettings & Модель налаштувань системи адміністратора сайту \\
\hline
\end{tabular}

2. SimulationLab.Api.Models - містить класи моделей передачі даних між підсистемами програмного комплексу (рис. 5, табл. 2).

\begin{tabular}{|l|}
\hline \multicolumn{1}{|c|}{ CreateSessionRequest } \\
\hline +Session: GameSessionDto \\
+Data: string \\
\hline
\end{tabular}

CreateSessionResponse

+Session: GameSessionDto

+Created: bool

+ FormHtml: string

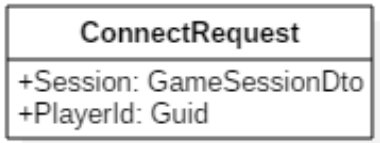

\section{ConnectResponse}

+Session: GameSessionDto +Connected: bool

+UpdateStatistics: bool

\begin{tabular}{l}
\hline \multicolumn{1}{|c|}{ GameActionRequest } \\
\hline +Session: GameSessionDto \\
+Playerld: Guid \\
+Data: string
\end{tabular}

\begin{tabular}{|l|}
\hline \multicolumn{1}{|c|}{ GameActionResponse } \\
\hline +Session: GameSessionDto \\
+PageHtml: string \\
+UpdatedPlayerslds: List< $<$ Guid> \\
+UpdateStatistics: bool
\end{tabular}

\begin{tabular}{|l|}
\multicolumn{1}{|c|}{ GamelnfoDto } \\
\hline +MainDescriptionHtml: string \\
+CreateSessionUrl: string \\
+ConnectUrl: string \\
+PageUrl: string \\
+SupportsPresentationPage: bool \\
+ForcedTransferToNextPageUrl: string \\
+StatisticsUrl: string \\
\hline
\end{tabular}

Pис. 5. Діаграма класів «SimulationLab.Api.Models» 
Onис класів «SimulationLab.Api.Models»

\begin{tabular}{|c|l|}
\hline Назва класу & \multicolumn{1}{|c|}{ Опис } \\
\hline CreateSessionRequest & Модель передачі даних створення сесії \\
\hline CreateSessionResponse & Модель передачі даних результату створення сесії \\
\hline ConnectRequest & Модель передачі даних підключення до сеансу симуляції \\
\hline ConnectResponse & Модель передачі даних результату підключення до сесії \\
\hline GameActionRequest & Модель передачі даних виконання запиту до симуляції \\
\hline GameActionResponse & Модель передачі даних результату запиту до симуляції \\
\hline GameInfoDto & Модель передачі даних налаштувань симуляції \\
\hline GameSessionDto & Модель передачі даних сесії симуляції \\
\hline GamePlayerDto & Модель передачі даних учасника сесії симуляції \\
\hline
\end{tabular}

3. SimulationLab.Engine - містить класи, які реалізовують основний функціонал програмного комплексу (рис. 6-9, табл. 3-6).

\begin{tabular}{l}
\multicolumn{1}{|c|}{ GameDbContext } \\
\hline -connectionString: string \\
+Sessions: DbSet<GameSession> \\
+Logins: DbSet<GameLogin> \\
+Players: DbSet<GamePlayer> \\
\hline $\begin{array}{l}\text { «constructor»+GameDbContext(connectionString: string) } \\
\text { \#OnConfiguring(optionsBuilder: DbContextOptionsBuilder): void } \\
\text { \#OnModelCreating(modelBuilder: ModelBuilder): void }\end{array}$ \\
\hline
\end{tabular}

\begin{tabular}{|l|}
\hline \multicolumn{1}{|c|}{ Gepository pattern } \\
\hline -connectionStrings: IOptions<ConnectionStrings> \\
\hline «constructor»+GameRepository(connectionStrings: IOptions<ConnectionStrings>) \\
+GetLogin(loginCode: string, withSession: bool): GameLogin \\
+GetSession(sessionld: Guid, withLogins: bool): GameSession \\
+GetPlayers(sessionld: Guid): IList<GamePlayer> \\
+SaveSessionAsync(session: GameSession): Task \\
+UpdateSession(session: GameSession): void \\
+SavePlayer(player: GamePlayer): void \\
+RemoveSessionsModifiedBeforeDate(modifiedDate: DateTime): void \\
\hline
\end{tabular}

Рис. 6. Діаграма класів «SimulationLab.Engine.Data»

Onис класів «SimulationLab.Engine.Data»

\begin{tabular}{|c|l|}
\hline Назва класу & \multicolumn{1}{|c|}{ Опис } \\
\hline GameDbContext & $\begin{array}{l}\text { Клас, що унаслідуваний від класу «DbContext». Представляє сеанс } 3 \\
\text { базою даних і використовується для запиту та збереження об’єктів }\end{array}$ \\
\hline GameRepository & $\begin{array}{l}\text { Реалізація патерну «Repository», яка дозволяє абстрагуватися від того як } \\
\text { зберігаються дані про проходження симуляції, } є \text { проміжною ланкою між } \\
\text { класами, які безпосередньо взаємодіють з даними і рештою програми }\end{array}$ \\
\hline
\end{tabular}




\begin{tabular}{|l|}
\hline \multicolumn{1}{|c|}{ Gamelnfo } \\
\hline +ld: Guid \\
+Name: string \\
+IsTest: bool \\
+Domain: string \\
+MainDescriptionHtml: string \\
+CreateSessionUrl: string \\
+SupportsCreateSessionAdditionalFields: bool \\
+ConnectUrl: string \\
+PageUrl: string \\
+SupportsPresentationPage: bool \\
+ForcedTransferToNextPageUrl: string \\
+SupportsForcedTransferToNextPage: bool \\
+StatisticsUrl: string \\
+SupportsStatistics: bool
\end{tabular}

\begin{tabular}{|l|}
\hline \multicolumn{1}{|c|}{ GameLogin } \\
\hline +Code: string \\
+Role: string \\
+Sessionld: Guid \\
+Session: GameSession \\
\hline «constructor»+GameLogin() \\
«constructor»+GameLogin(code: string, role: string)
\end{tabular}

\begin{tabular}{|l|}
\hline \multicolumn{1}{|c|}{ GameContext } \\
\hline +Gameld: Guid \\
+GameName: string \\
+Sessionld: Guid \\
+Userld: Guid \\
+PlayerLoginCode: string \\
\hline
\end{tabular}

\begin{tabular}{|l|}
\hline \multicolumn{1}{|c|}{ GameSession } \\
\hline +Id: Guid \\
+Gameld: Guid \\
+Logins: List<GameLogin> \\
+Players: List<GamePlayer> \\
+MaxNumberOfPlayers: int \\
+ModifiedDate: DateTime \\
+Data: string \\
\hline
\end{tabular}

\begin{tabular}{|l|}
\hline \multicolumn{1}{|c|}{ GamePlayer } \\
\hline +ld: Guid \\
+Sessionld: Guid \\
+Session: GameSession \\
+IsBot: bool \\
+Name: string \\
+Order: int \\
+CurrentPageNumber: int \\
+CurrentPageName: string \\
+IsAwaiting: bool \\
+LastActive: DateTime \\
+Data: string \\
\hline
\end{tabular}

\begin{tabular}{l} 
GameManifest \\
\hline +Id: Guid \\
+Name: string \\
+GamelnfoUrl: string \\
+Order: int \\
+IsTest: bool \\
+FilePath: string
\end{tabular}

\begin{tabular}{|l|}
\hline \multicolumn{1}{|c|}{ CreateSessionResult } \\
\hline +Created: bool \\
+PlayerLoginCode: string \\
+InstructorLoginCode: string \\
+FormHtml: string \\
\hline
\end{tabular}

\section{ConnectResult}

+Connected: bool +UpdateStatistics: bool

\begin{tabular}{|l|}
\hline \multicolumn{1}{|c|}{ GameActionResult } \\
\hline +PageHtml: string \\
+UpdatedPlayerslds: List< $<$ Guid >> \\
+UpdateStatistics: bool \\
+IsSessionModified: bool
\end{tabular}

\begin{tabular}{|l|}
\hline \multicolumn{1}{|c|}{ GameSettings } \\
\hline +DirectoryPath: string \\
+LoginCodeLength: int \\
\hline
\end{tabular}

Puс. 7. Діаграма класів «SimulationLab.Engine.Models»

Oпис класів «SimulationLab. Engine.Models»

\begin{tabular}{|c|l|}
\hline Назва класу & \multicolumn{1}{|c|}{ Опис } \\
\hline ConnectionStrings & Модель даних строк підключень \\
\hline GameInfo & Модель даних інформації про симуляцію \\
\hline GameLogin & Модель даних логіна до сеансу симуляції \\
\hline GameSession & Модель даних сеансу симуляції \\
\hline GamePlayer & Модель даних учасника сеансу симуляції \\
\hline GameManifest & Модель даних реєстрації симуляції в системі \\
\hline GameSettings & Модель даних загальних налаштувань симуляцій \\
\hline GameRoles & $\begin{array}{l}\text { Модель з константами всіх можливих ролей, які можуть мати } \\
\text { користувачі в системі }\end{array}$ \\
\hline GameContext & Модель з даними поточного сеансу симуляції \\
\hline CreateSessionResult & Модель даних результату створення сеансу симуляції \\
\hline ConnectResult & Модель даних результату підключення до сеансу симуляції \\
\hline GameActionResult & Модель даних результату виконання запиту до симуляції \\
\hline
\end{tabular}




\begin{tabular}{|c|}
\hline Singleton pattern \\
\hline GameService \\
\hline $\begin{array}{l}\text {-gameManifestFactory: GameManifestFactory \{readOnly\} } \\
\text {-gamelnfoFactory: GamelnfoFactory \{readOnly\} } \\
\text {-gameRepository: GameRepository \{readOnly\} } \\
\text {-httpClientFactory: IHttpClientFactory \{readOnly\} } \\
\text {-settings: IOptions<GameSettings> \{readOnly\} } \\
\text {-mapper: IMapper \{readOnly\} } \\
\text {-random: Random \{readOnly\} }\end{array}$ \\
\hline $\begin{array}{l}\text { «constructors+GameService(gameManifestFactory: GameManifestFactory, } \\
\text { gamelnfoFactory: GamelnfoFactory, gameRepository: GameRepository, } \\
\text { httpClientFactory: IHttpClientFactory, settings: IOptions<GameSettings>, mapper: } \\
\text { IMapper) } \\
\text {-InitializeGames(): void } \\
\text { +GetCreateSessionAdditionalFieldsAsync(gameld: Guid): Task<string> } \\
\text { +CreateSessionAsync(gameld: Guid, data): Task<CreateSessionResult> } \\
\text { +Connect(sessionld: Guid, playerld: Guid): ConnectResult } \\
\text { +ConnectBot(sessionld: Guid, playerld: Guid, order: int): ConnectResult } \\
\text { +FillSessionWithBots(sessionld: Guid): ConnectResult } \\
\text { +ConnectCore(sessionld: Guid, playerld: Guid, onCreate: Action<GamePlayer>, } \\
\text { onUpdate: Action<GamePlayer>): ConnectResult } \\
\text { +GetGamePage(sessionld: Guid, playerld: Guid): GameActionResult } \\
\text { +PostGameForm(sessionld: Guid, playerld: Guid, url: string, data): GameActionResult } \\
\text { +TransferToNextPage(sessionld: Guid, playerld: Guid): GameActionResult } \\
\text { +UpdateBots(sessionld: Guid): GameActionResult } \\
\text {-ExecuteGameActionRequest(sessionld: Guid, playerld: Guid, getUrl, } \\
\text { prepareRequest, canExecute): GameActionResult } \\
\text { +GetStatisticsAsync(sessionld: Guid): Task<string> } \\
\text {-ConvertToAbsoluteUrl(url, string, domain: string): string } \\
\text {-SerializePostData(data: object): string } \\
\text {-ModifySession(session: GameSession, sessionDto: GameSessionDto): bool } \\
\text {-ModifyPlayer(player: GamePlayer, playerDto: GamePlayerDto): bool }\end{array}$ \\
\hline
\end{tabular}

\begin{tabular}{|l|}
\hline \multicolumn{1}{|c|}{ GameManifestService } \\
\hline $\begin{array}{l}\text {-gameManifestFactory: GameManifestFactory }\{\text { readOnly\} } \\
\text {-settings: IOptions<GameSettings> \{readOnly\} }\end{array}$ \\
\hline $\begin{array}{l}\text { «constructor»+GameManifestService(gameManifestFactory: } \\
\text { GameManifestFactory, settings: IOptions<GameSettings }>\text { ) } \\
\text {-InitializeGames(): void } \\
\text { +SaveManifest(manifest): void } \\
\text { +DeleteManifest(manifest): void }\end{array}$ \\
\hline
\end{tabular}

\begin{tabular}{|l|}
\hline Singleton pattern \\
\hline GamelnfoFactory \\
\hline -dictionary: IDictionary<Guid, Gamelnfo> \\
\hline +InitializeWith(dictionary): void \\
+GetAllGames(): IList<Gamelnfo> \\
+GetGamelnfo(id: Guid): Gamelnfo \\
\hline
\end{tabular}

\begin{tabular}{l|}
\multicolumn{1}{|c|}{ Singleton pattern } \\
\hline $\begin{array}{l}\text {-collection: IList<GameManifestFactory } \\
\text { +Initialized: EventHandler }\end{array}$ \\
\hline $\begin{array}{l}\text { +InitializeWith(collection: IList<GameManifest>): void } \\
\text { +GetAllManifests(): IList< GameManifest> } \\
\text { +GetManifest(id: Guid): GameManifest }\end{array}$ \\
\hline
\end{tabular}

Рис. 8. Діаграма класів «SimulationLab.Engine.Services»

Таблиия 5

Опис класів «SimulationLab.Engine.Services»

\begin{tabular}{|c|l|}
\hline Назва класу & \multicolumn{1}{|c|}{ Опис } \\
\hline GameService & $\begin{array}{l}\text { Клас для створення, виконання та оброблення результатів запитів до } \\
\text { мікросервісів симуляцій }\end{array}$ \\
\hline GameManifestService & $\begin{array}{l}\text { Клас для виконання ініціалізації та виконання операції створення, } \\
\text { редагування та видалення маніфестів симуляцій }\end{array}$ \\
\hline GameInfoFactory & $\begin{array}{l}\text { Реалізація патерну «Flyweight» для збереження об’єктів 3 інформацією } \\
\text { про симуляції }\end{array}$ \\
\hline GameManifestFactory & $\begin{array}{l}\text { Реалізація патерну «Flуweight» для збереження об’єктів 3 інформацією } \\
\text { про маніфести симуляцій }\end{array}$ \\
\hline
\end{tabular}

\begin{tabular}{|c|c|}
\hline \multicolumn{2}{|l|}{ Template method pattern } \\
\hline \multicolumn{2}{|c|}{ HttpOperationBase } \\
\hline \multicolumn{2}{|c|}{$\begin{array}{l}\text { \#httpClient: HttpClient \{readOnly\} } \\
\text { \#url: string }\{\text { readOnly\} }\end{array}$} \\
\hline \multicolumn{2}{|c|}{$\begin{array}{l}\text { «constructor»+HttpOperationBase(httpClient: HttpClient, url: string) } \\
+ \text { +ExecuteAsync(): Task<HttpOperationResult> }\end{array}$} \\
\hline HttpGetOperation & HttpPostOperation \\
\hline $\begin{array}{l}\text { «constructor»+HttpGetOperation() } \\
+ \text { +ExecuteAsync(): Task<HttpOperationResult }>\end{array}$ & \#content: string \{readOnly\} \\
\hline +ExecuteAsync(): Task<HittpOperationResult> & $\begin{array}{l}\text { «constructors +HttpPostOperation(httpClient: HttpClient, url: string, } \\
\text { content: string) } \\
\text { +ExecuteAsync(): Task<HttpOperationResult> }\end{array}$ \\
\hline
\end{tabular}

\begin{tabular}{|l|}
\hline \multicolumn{1}{|c|}{ HttpOperationResult } \\
\hline +StatusCode: HttpStatusCode \\
+IsSuccessStatusCode: bool \\
+Content: string \\
\hline
\end{tabular}

Pис. 9. Діаграма класів «SimulationLab.Engine.Services.Operations» 
Onис класів «SimulationLab.Engine.Services.Operations»

\begin{tabular}{|c|l|}
\hline Назва класу & \multicolumn{1}{|c|}{ Опис } \\
\hline HttpOperationResult & Модель даних з результатом запиту до мікросервісу \\
\hline HttpOperationBase & $\begin{array}{l}\text { Реалізація патерну «Template method». Клас } є \text { базовим для класів, які } \\
\text { призначені для виконання запитів різних типів до мікросервісів }\end{array}$ \\
\hline HttpGetOperation & $\begin{array}{l}\text { Клас унаслідуваний від класу «HttpOperationBase». Необхідний для } \\
\text { виконання запитів типу «GET»до мікросервісів }\end{array}$ \\
\hline HttpPostOperation & $\begin{array}{l}\text { Клас унаслідуваний від класу «HttpOperationBase». Необхідний для } \\
\text { виконання запитів типу «POST»до мікросервісів }\end{array}$ \\
\hline
\end{tabular}

4. SimulationLab.Core - містить загальні допоміжні класи, які можуть знадобитися в будь-якому іншому компоненті програмного комплексу (рис. 10, табл. 7).
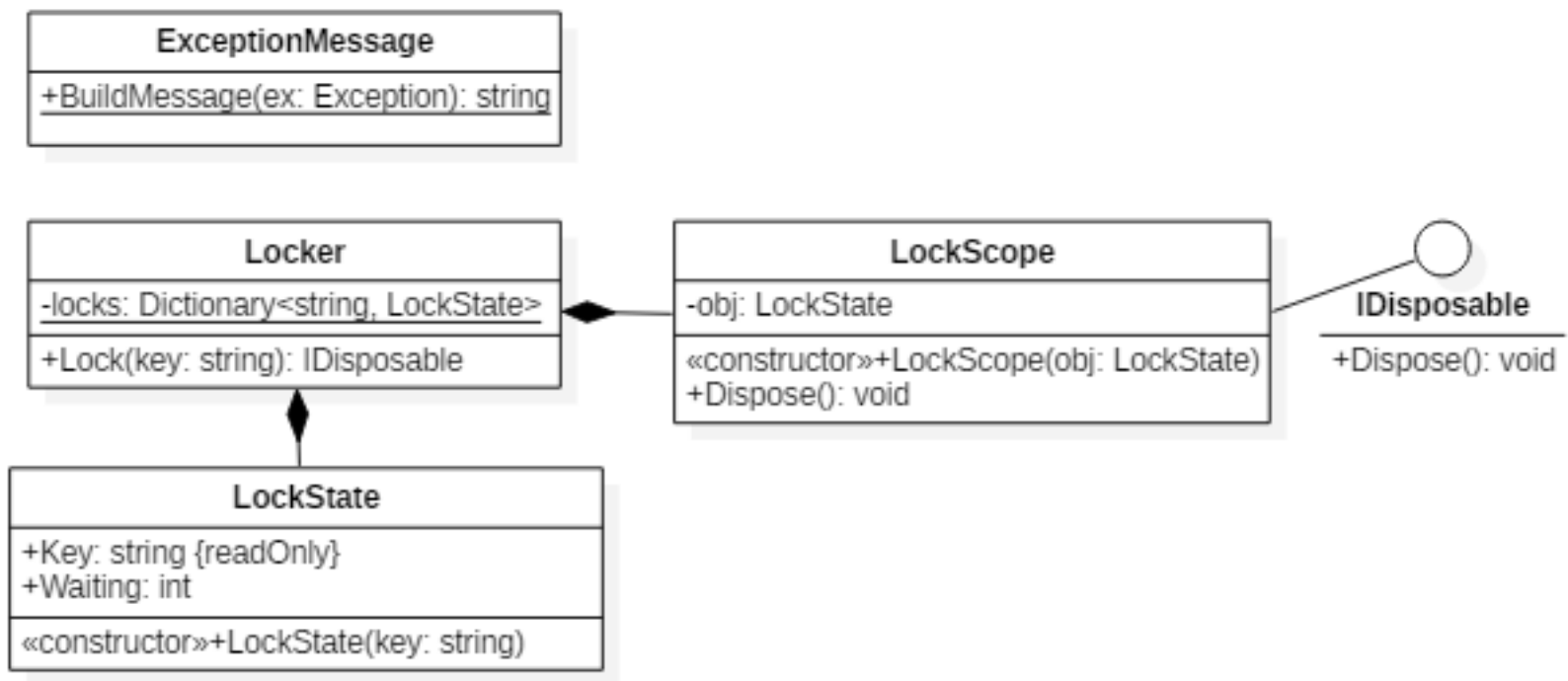

Puc. 10. Діаграма класів «SimulationLab.Core»

Опис класів «SimulationLab.Core»

Таблиияя 7

\begin{tabular}{|c|l|}
\hline Назва класу & \multicolumn{1}{|c|}{ Опис } \\
\hline ExceptionMessage & Допоміжний клас для побудови повідомлення про помилку \\
\hline Locker & $\begin{array}{l}\text { Допоміжний клас для синхронізованого доступу до ділянок коду за } \\
\text { ключем }\end{array}$ \\
\hline LockState & $\begin{array}{l}\text { Внутрішній клас класу «Locker» для збереження ключа блокування та } \\
\text { кількості потоків, які чекають доступу для виконання заблокованого коду }\end{array}$ \\
\hline LockScope & $\begin{array}{l}\text { Внутрішній клас класу «Locker» для створення окремої ділянки коду, } \\
\text { доступ до якої має бути синхронізований. } \\
\text { Реалізовує інтерфейс «IDisposable» }\end{array}$ \\
\hline
\end{tabular}

5. SimulationLab.Web - містить класи контролерів, моделей-представлень, представлення, файли скриптів та файли зі стилями (рис. 11-14, табл. 8-11). 


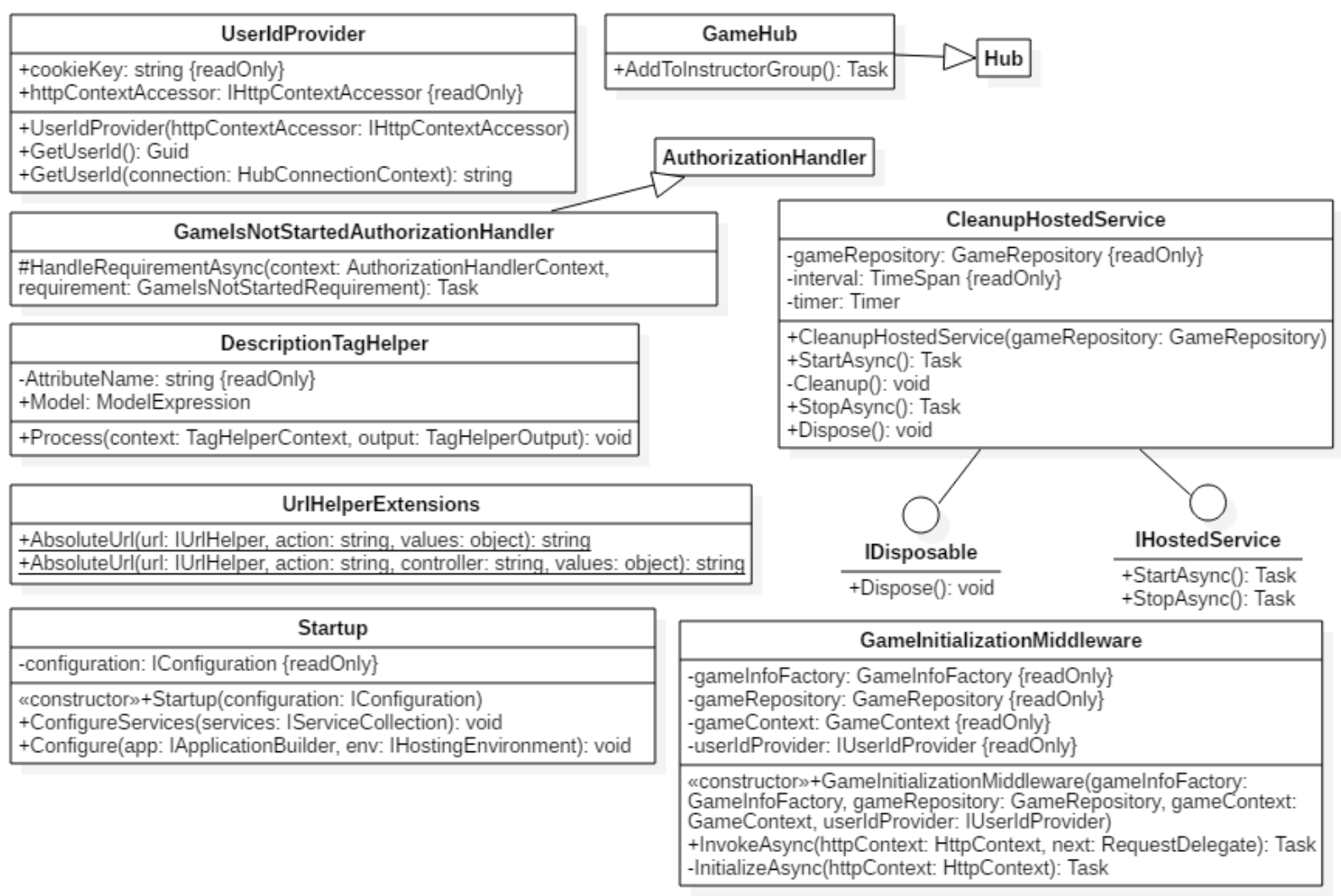

Puc. 11. Діаграма класів «SimulationLab.Web»

Oпис класів «SimulationLab.Web»

\begin{tabular}{|c|c|}
\hline Назва класу & Опис \\
\hline UserIdProvider & $\begin{array}{l}\text { Клас для генерації чи визначення унікального } \\
\text { ідентифікатора учасника симуляції }\end{array}$ \\
\hline GameHub & $\begin{array}{l}\text { Клас унаслідуваний від «Нub». Необхідний для } \\
\text { створення 3’єднання між браузером та сервером } \\
\text { для обміну повідомленнями в режимі реального } \\
\text { часу }\end{array}$ \\
\hline CleanupHostedService & $\begin{array}{l}\text { Клас реалізує інтерфейси «IHostedService» та } \\
\text { «IDisposable». Необхідний для видалення } \\
\text { застарілих даних сеансів симуляцій }\end{array}$ \\
\hline GameInitializationMiddleware & $\begin{array}{l}\text { Клас реалізує інтерфейс «IMiddleware». } \\
\text { Необхідний для ініціалізації контексту поточного } \\
\text { сеансу симуляції }\end{array}$ \\
\hline DescriptionTagHelper & $\begin{array}{l}\text { Допоміжний клас унаслідуваний від «TagHelper» } \\
\text { для створення тексту з описом поля }\end{array}$ \\
\hline UrlHelperExtensions & $\begin{array}{l}\text { Клас } 3 \text { допоміжними методами для побудови } \\
\text { абсолютних URL адрес }\end{array}$ \\
\hline GameIsNotStartedAuthorizationHandler & 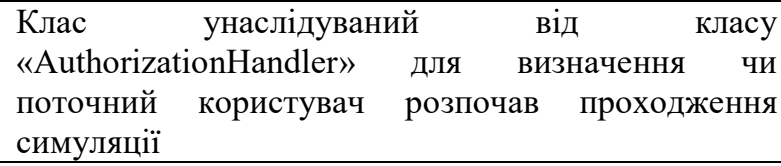 \\
\hline Startup & Клас для конфігурації додатку \\
\hline
\end{tabular}




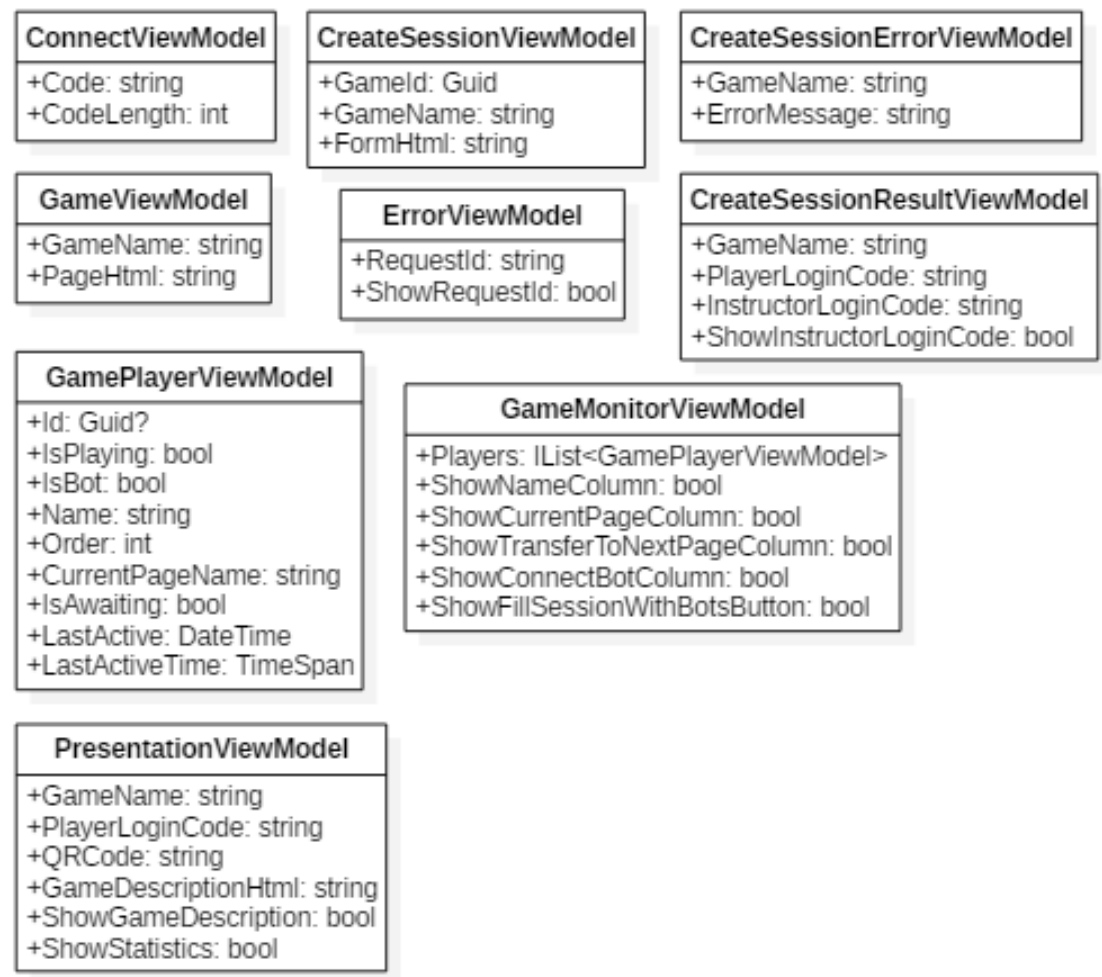

Puc. 12. Діаграма класів «SimulationLab.Web.Models»

Oпис класів «SimulationLab.Web.Models»

\begin{tabular}{|c|l|}
\hline Назва класу & \multicolumn{1}{|c|}{ Опис } \\
\hline ConnectViewModel & $\begin{array}{l}\text { Модель представлення сторінки з формою підключення до сеансу } \\
\text { симуляції }\end{array}$ \\
\hline CreateSessionViewModel & Модель представлення форми створення сеансу симуляції \\
\hline CreateSessionErrorViewModel & $\begin{array}{l}\text { Модель представлення повідомлення про те, що сеанс симуляції } \\
\text { створити не вдалося }\end{array}$ \\
\hline CreateSessionResultViewModel & $\begin{array}{l}\text { Модель представлення повідомлення про те, що сеанс симуляції } \\
\text { успішно створено }\end{array}$ \\
\hline ErrorViewModel & Модель представлення сторінки з інформацію про помилку \\
\hline GameViewModel & Модель представлення сторінки симуляції \\
\hline PresentationViewModel & Модель представлення сторінки інструктора \\
\hline GameMonitorViewModel & Модель представлення вкладки «Мопітог»на сторінці інструктора \\
\hline GamePlayerViewModel & Модель представлення інформації про учасника симуляції \\
\hline
\end{tabular}

Oпис класів «SimulationLab.Web.Controllers»

Табличя 10

\begin{tabular}{|c|l|}
\hline Назва класу & \multicolumn{1}{|c|}{ Опис } \\
\hline \multirow{2}{*}{ GamesController } & $\begin{array}{l}\text { Клас унаслідуваний від класу «Controller». Є основним класом для } \\
\text { генерації моделей та представлень що пов’язані зі створенням та } \\
\text { проведенням числових симуляцій }\end{array}$ \\
\hline ErrorsController & $\begin{array}{l}\text { Клас унаслідуваний від класу «Controller». Повертає представлення } 3 \\
\text { інформацією про помилки }\end{array}$ \\
\hline
\end{tabular}




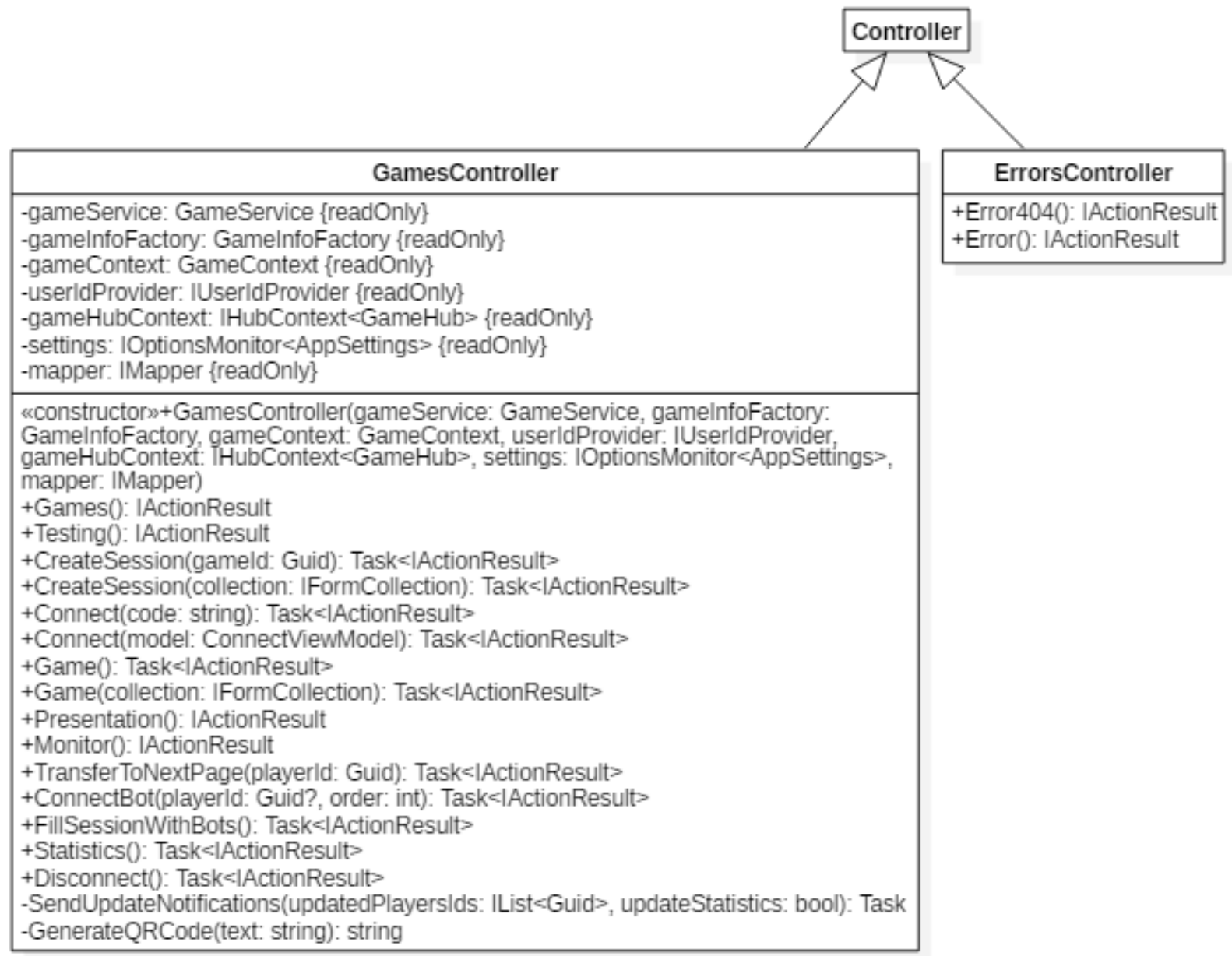

Puс. 13. Діаграма класів «SimulationLab.Web.Controllers»
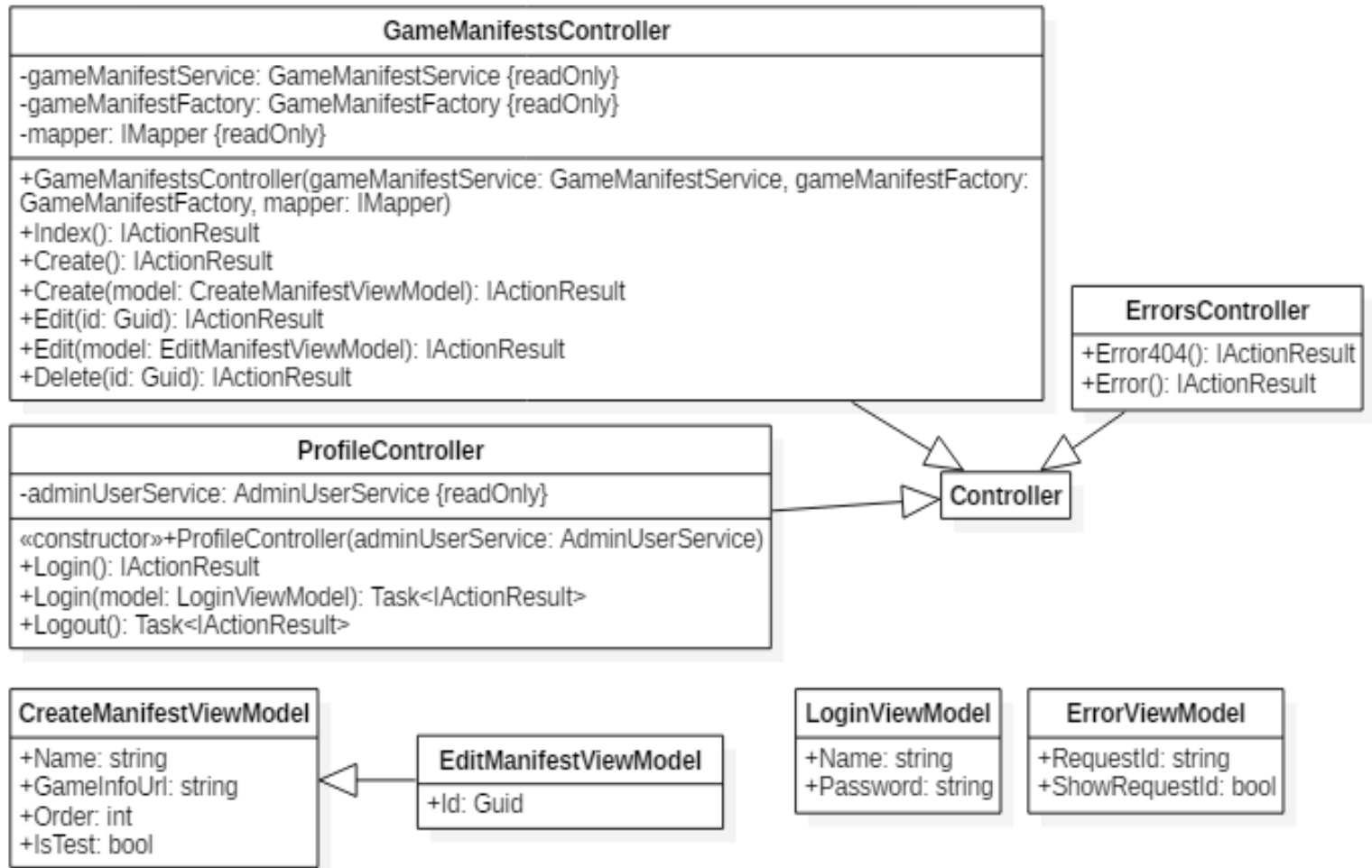

Puc. 14. Діаграма класів «SimulationLab.Web.Admin» 
Опис класів «SimulationLab.Web.Admin»

\begin{tabular}{|c|l|}
\hline Назва класу & \multicolumn{1}{|c|}{ Опис } \\
\hline GameManifestsController & $\begin{array}{l}\text { Клас унаслідуваний від класу «Controller». Генерує моделі та } \\
\text { повертає представлення пов’язані з маніфестами симуляцій }\end{array}$ \\
\hline ProfileController & $\begin{array}{l}\text { Клас унаслідуваний від класу «Controller». Генерує моделі та } \\
\text { повертає представлення пов’язані з аутентифікацією користувача } \\
\text { в системі адміністратора }\end{array}$ \\
\hline ErrorsController & $\begin{array}{l}\text { Клас унаслідуваний від класу «Сопtroller». Повертає } \\
\text { представлення з інформацією про помилки }\end{array}$ \\
\hline LoginViewModel & $\begin{array}{l}\text { Модель представлення сторінки аутентифікації користувача в } \\
\text { системі адміністратора }\end{array}$ \\
\hline CreateManifestViewModel & Модель представлення сторінки створення маніфесту симуляції \\
\hline EditManifestViewModel & Модель представлення сторінки редагування маніфесту симуляції \\
\hline ErrorViewModel & Модель представлення сторінки з інформацією про помилку \\
\hline
\end{tabular}

\section{Структура інтерфейсу програмного комплексу}

Програмний комплекс створення та проведення числових симуляцій $є$ веб-додатком, який розгорнутий в мережі Інтернет. Режим доступу: https://simulationlab.azurewebsites.net.

Розроблений програмний комплекс підтримує такі ролі користувачів:

- «Адміністратор»;

- «Нструктор»;

- «Учасник».

Для того щоб зрозуміти. які можливості мають користувачі з перерахованими вище ролями, було зроблено опис функціональності сайту через його варіанти використання.

На рисунку 15 зображено діаграму варіантів використання сайту користувача 3 роллю «Адміністратор». На діаграмі видно, що користувач з цією роллю має такі варіанти використання:

1. Доступ до системи контролю над сайтом - спеціальної сторінки, яка $є$ прихованою від користувачів з іншими ролями.

2. Додавання маніфесту симуляції, який має містити такі дані:

a) назву симуляції;

b) шлях (URL) до місця, де система зможе знайти налаштування симуляції;

c) число, яке буде використано при сортуванні симуляцій в каталозі (менше число означає те, що симуляція буде в списку вище);

d) вказати, чи дана симуляція знаходиться на стадії тестування, щоб система помістила такі симуляції в окремий каталог.

3. Редагування маніфесту симуляції. При редагуванні маніфесту можна змінювати всі перераховані вище дані, які були заповнені при створенні маніфесту симуляції.

4. Видалення маніфесту симуляції.

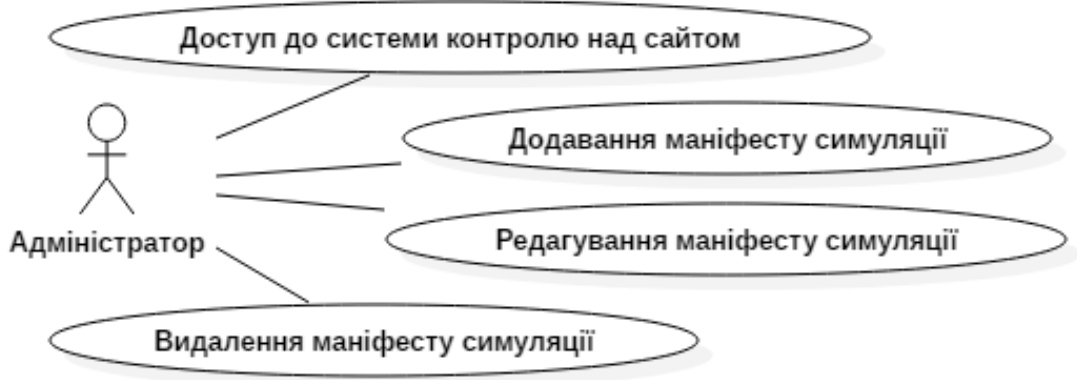

Рис. 15. Діаграма варіантів використання сайту користувача з роллю «Адміністратор»

На рисунку 16 зображено діаграму варіантів використання сайту користувача 3 роллю «Інструктор». На діаграмі видно, що користувач з цією роллю має такі варіанти використання:

1. Доступ до сторінки презентації сеансу симуляції, яка містить дані про те, як учасникам приєднатися до сеансу симуляції.

2. Створення сеансу симуляції. 
3. Перегляд даних про активність учасників симуляції. Ця сторінка також дає інформацію про те, скільки всього гравців підключено до сеансу і скільки ще є вільних місць.

4. Заповнення вільних місць сеансу ботами. Для випадків, коли кількість учасників є недостатньою для проходження симуляції.

5. Переведення учасника симуляції на наступний крок. Для випадків, коли учасник почав проходження симуляції, але є довго неактивним.

6. Заміна учасника симуляції ботом. Ця дія є невідворотною і необхідна лише для випадків, коли учасник почав проходження, але більше не зможе продовжити далі.

7. Перегляд загальної статистики сеансу симуляції.

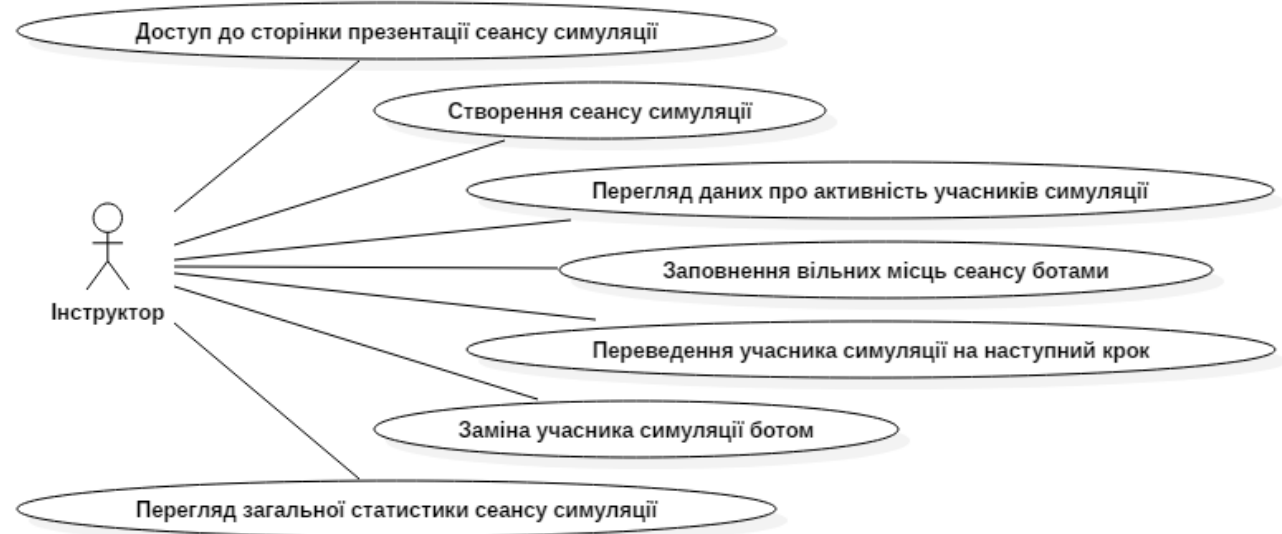

Рис. 16. Діаграма варіантів використання сайту користувача з роллю «Інструктор»

На рисунку 17 зображено діаграму варіантів використання сайту користувача з роллю «Учасник». На діаграмі видно, що користувач 3 цією роллю має лише можливість приєднатися до сеансу симуляції та проходити його.

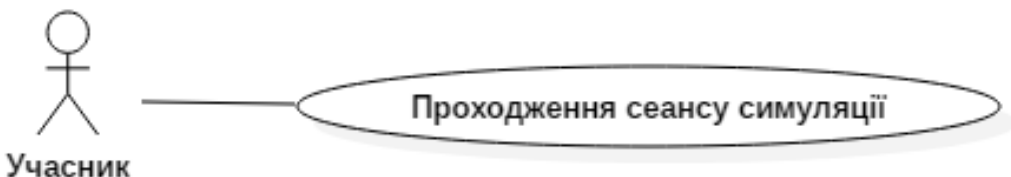

Рис. 17. Діаграма варіантів використання сайту користувача з роллю «Учасник»

Висновки та перспективи подальших досліджень. У цій роботі було спроектовано та реалізовано програмний комплекс створення та проведення числових симуляцій. Використання засобів навчання, що збагачують пізнавальний досвід студентів та забезпечують вироблення умінь та навичок, значною мірою залежить від зручності впровадження таких засобів у освітній процес викладачем, тому велика увага в роботі приділялася саме зручному впровадженню використання розробленої системи під час лекцій чи практичних занять. Система побудована з використанням сучасних технологій та архітектурних рішень.

Використання розробленої системи значно спрощує доповнення теоретичного матеріалу практичними та дослідницькими видами навчальної діяльності в межах курсів математичного та соціально-економічних блоків у закладах вищої та загальної середньої освіти, корпоративних тренінгах та в межах заходів неформальної освіти.

Система забезпечує розширення бібліотеки симуляцій, що дає можливість доповнити в подальшому реалізований програмний комплекс новими симуляціями, які можуть бути розроблені незалежно від основної системи.

\section{Список використаної літератури:}

1. Бізнес-симуляція [Електронний ресурс]. - Режим доступу : https://uk.wikipedia.org/wiki/Бізнес-симуляція.

2. Вакалюк T.A. Використання хмарних бізнес-симуляторів для вивчення поведінкової економіки / T.A. Вакалюк Д.С. Антонюк // Наукова молодь-2016 : збірник матеріалів IV Всеукраїнської науковопрактичної конференції молодих учених (15 груд. 2016 р., м. Київ) ; за заг. ред. проф. О.М. Спіріна. - К. : ІІТЗН НАПН України, 2016. - С. 53-56 [Електронний ресурс]. - Режим доступу : http://lib.iitta.gov.ua/707095. 
3. Антонюк Д.С. Використання програмно-імітаційних комплексів як засобів формування економічних компетентностей студентів технічних спеціальностей : дис. ... канд. пед. наук : 13.00 .10 / Д.С. Антонюк. Київ, 2018.

4. The Market for Lemons [Електронний ресурс]. - Режим доступу : https://en.wikipedia.org/wiki/The_Market_for_Lemons.

5. Bruehler James R. The Red/Green Simulation / James R. Bruehler, Alan P. Grant, Linda S. Ghent // Journal of Economics and Finance Education. - 2017. - Vol. 16, Issue 1 [Електронний ресурс]. - Режим доступу : https://www.economics-finance.org/jefe/issues/JEFE-Vol-16-Num-1-Winter-2017.pdf.

6. Об'єктно-орієнтоване програмування [Електронний ресурс]. - Режим доступу : https://uk.wikipedia.org/wiki/Об'єктно-орієнтоване_програмування.

7. Bring your own device [Електронний pecypc]. - Режим доступу: https://uk.wikipedia.org/wiki/Bring_your_own_device.

8. Мікросервіси [Електронний ресурс]. - Режим доступу : https://uk.wikipedia.org/wiki/Miкросервіси.

9. Модель-вид-контролер [Електронний ресурс]. - Режим доступу : https://uk.wikipedia.org/wiki/Модель-видконтролер.

10. Architectural principles [Електронний pecypc]. - Режим доступу : https://docs.microsoft.com/enus/dotnet/standard/modern-web-apps-azure-architecture/architectural-principles.

11. Adams W.K. Student engagement and learning with PhET interactive simulations / W.K. Adams [Електронний pecypc]. - Режим доступу : http://www.jdes.tyc.edu.tw/PhET2013/publications/MPTL_2010_PhET_final.pdf.

12. Castronova Edward Exodus to the Virtual World: How Online Fun is Changing Reality / Edward Castronova // Palgrave Macmillan [Електронний pecypc]. http://us.macmillan.com/exodustothevirtualworld/edwardcastronova

13. Liang T. Classical atomistic simulations of surfaces and heterogeneous interfaces with the charge-optimized many body (COMB) potentials / T.Liang, T.R. Shan // Materials Science and Engineering. - R. : Reports, 2013. - Vol. 74, Issue 9, P. 255-279.

14. Podolefsky N.S. Computer simulations to classrooms: tools for change / N.S. Podolefsky, K.K. Perkins, W.K. Adams // Physics Education Research : Conference Proceedings. - AIP Press, 2010 [Електронний ресурс]. - Режим доступу : https://www.colorado.edu/physics/EducationIssues/papers/Podolefsky_etal/Podolefsky_invited_PERC_09_scales_revis ed.pdf.

15. Fortmann-Roe Scott Insight Maker: A general-purpose tool for web-based modeling \& simulation / Scott Fortmann-Roe // Simulation Modelling Practice and Theory. - 2014. - № 47. - P. 28-45 [Електронний ресурс]. Режим доступу : https://www.researchgate.net/publication/263127834_Insight_Maker_A_generalpurpose_tool_for_web-based_modeling_simulation.

16. Шендерук О.Б. Технології ситуативного моделювання. Симуляції або імітаційні ігри // О.Б. Шендерук, B.А. Пермінова [Електронний ресурс]. - Режим доступу : http://www.rusnau k a.com/26_SSN_2010/P hilologia/71388.doc.htm.

17. Мацџюк O.O. Комп’ютерні симуляції як засіб формування професійної компетентності майбутніх перекладачів в умовах інформаційного суспільства / О.О. Мацюк // Вісник Національної академії Державної прикордонної служби України. - 2013. - Вип. 5 [Електронний ресурс]. - Режим доступу : http://nbuv.gov.ua/UJRN/Vnadps_2013_5_20.

\section{References:}

1. Biznes-symuljacija, [Online], available at: https://uk.wikipedia.org/wiki/Biznes-symuliatsiia

2. Vakaljuk, T.A. and Antonjuk, D.S. (2016), «Vykorystannja hmarnyh biznes-symuljatoriv dlja vyvchennja povedinkovoi' ekonomiky», Naukova molod'-2016, zbirnyk materialiv IV Vseukrai'ns'koi' naukovo-praktychnoi' konferencii' molodyh uchenyh (15 grud. 2016 r., m. Kyi'v), za zag. red. prof. O.M. Spirina, IITZN NAPN Ukrai'ny, K., pp. 53-56, [Online], available at: http://lib.iitta.gov.ua/707095

3. Antonjuk, D.S. (2018), «Vykorystannja programno-imitacijnyh kompleksiv jak zasobiv formuvannja ekonomichnyh kompetentnostej studentiv tehnichnyh special'nostej», Ph.D. Thesis of diss., 13.00.10., Kyiv.

4. The Market for Lemons, [Online], available at: https://en.wikipedia.org/wiki/The_Market_for_Lemons

5. Bruehler, James R., Grant, Alan P. and Ghent, Linda S. (2017), «The Red/Green Simulation», Journal of Economics and Finance Education, Vol. 16, Issue 1, [Online], available at: https://www.economicsfinance.org/jefe/issues/JEFE-Vol-16-Num-1-Winter-2017.pdf

6. Ob'jektno-orijentovane programuvannja, [Online], available at: https://uk.wikipedia.org/wiki/Obiektnooriientovane_prohramuvannia

7. Bring your own device, [Online], available at: https://uk.wikipedia.org/wiki/Bring_your_own_device

8. Mikroservisy, [Online], available at: https://uk.wikipedia.org/wiki/Mikroservisy

9. Model-vyd-kontroler, [Online], available at: https://uk.wikipedia.org/wiki/Model-vyd-kontroler

10. Architectural principles, [Online], available at: https://docs.microsoft.com/en-us/dotnet/standard/modern-webapps-azure-architecture/architectural-principles

11. Adams, W.K., Student engagement and learning with PhET interactive simulations, [Online], available at: ttp://www.jdes.tyc.edu.tw/PhET2013/publications/MPTL_2010_PhET_final.pdf

12. Castronova, E., Exodus to the Virtual World: How Online Fun is Changing Reality, Palgrave Macmillan, [Online], available at: http://us.macmillan.com/exodustothevirtualworld/edwardcastronova 
13. Liang, T. and Shan, T.R. (2013), «Classical atomistic simulations of surfaces and heterogeneous interfaces with the charge-optimized many body (COMB) potentials», Materials Science and Engineering, Reports, R., Vol. 74, Issue 9, pp. 255-279.

14. Podolefsky, N.S., Perkins, K.K. and Adams, W.K. (2010), «Computer simulations to classrooms: tools for change», Physics Education Research, Conference Proceedings, AIP Press, [Online], available at: https://www.colorado.edu/physics/EducationIssues/papers/Podolefsky_etal/Podolefsky_invited_PERC_09_scales_r evised.pdf

15. Fortmann-Roe, Scott (2014), «Insight Maker: A general-purpose tool for web-based modeling \& simulation», Simulation Modelling Practice and Theory, No. 47, pp. 28-45, [Online], available at: https://www.researchgate.net/publication/263127834_Insight_Maker_A_general-purpose_tool_for_webbased_modeling_simulation

16. Shenderuk, O.B. and Perminova, V.A. (2010), Tehnologii' sytuatyvnogo modeljuvannja. Symuljacii' abo imitacijni igry, [Online], available at: http://www.rusnau k a.com/26_SSN_2010/P hilologia/71388.doc.htm

17. Macjuk, O.O. (2013), «Komp'juterni symuljacii' jak zasib formuvannja profesijnoi' kompetentnosti majbutnih perekladachiv v umovah informacijnogo suspil'stva», Visnyk Nacional'noi' akademii' Derzhavnoi' prykordonnoi' sluzhby Ukrai'ny, Issue 5, [Online], available at: http://nbuv.gov.ua/UJRN/Vnadps_2013_5_20

Морозов Андрій Васильович - кандидат технічних наук, доцент, доцент Державного університету «Житомирська політехніка».

Наукові інтереси:

- інженерія програмного забезпечення.

E-mail: morozov.andriy@gmail.com.

ORCID: 0000-0003-3167-0683

Вакалюк Тетяна Анатоліївна - кандидат педагогічних наук, доцент, професор Державного університету «Житомирська політехніка».

Наукові інтереси:

- інформаційно-комунікаційні технології;

- хмарні сервіси, теорія і методика навчання (інформатика);

-

E-mail: tetianavakaliuk@gmail.com.

ORCID: 0000-0001-6825-4697

Антонюк Дмитро Сергійович - кандидат педагогічних наук, доцент Державного університету «Житомирська політехніка».

Наукові інтереси:

- програмно-імітаційні комплекси;

- бізнес-симуляції, розробка бізнес-симуляцій;

- інженерія програмного забезпечення.

E-mail: dmitry_antonyuk@yahoo.com.

ORCID: 0000-0001-7496-3553

Дідківський Владислав Валентинович - студент 1 курсу магістратури факультету інформаційнокомп’ютерних технологій Державного університету «Житомирська політехніка».

Наукові інтереси:

- розробка бізнес-симуляцій;

-

E-mail: v.didkivskyi@sana-commerce.com.

ORCID: 0000-0002-4615-7578 